\title{
Factors that Influence Tourist Buying Interest in Manado City Traditional SMEs
}

\author{
Imelda W. J. Ogi*, Merinda H. Ch. Pandowo, Rita N. Taroreh \\ Faculty of Economy and Business \\ Universitas Sam Ratulangi \\ Manado, Indonesia \\ *ogi_imelda@unsrat.ac.id
}

\begin{abstract}
Small businesses in Manado are on of the pillars in supporting economic growth in this area. SMEs also support the development of innovation in supporting the tourism industry in this city. Problems faced by SMEs in Manado include how SMEs in Manado, especially traditional SMEs, in predicting consumer behavior especially tourist behavior in Manado. The research objective is to analyze the factors that influence the buying interest of tourists in traditional SMEs in the city of Manado. The research method is quantitative with the object of research in traditional food and beverage based SMEs in the city of Manado. The number of samples is 100 respondents taken from 10 SMEs. The results obtained information related to variables affecting the buying interest of tourists in the city of Manado.
\end{abstract} City

Keywords: tourist buying interest, traditional SMEs, Manado

\section{INTRODUCTION}

North Sulawesi's economic growth rate based on Compound Annual Growth Rate data, abbreviated as CAGR, ranks first in Indonesia, at 66 percent. The growth rate of North Sulawesi (North Sulawesi) is three times the growth rate of Indonesian tourism, which is 22 percent. Behind this rapid rise, tourism as one of the main sectors in Indonesia and North Sulawesi is worth seeing. The majority of tourists enter through the Sam Ratulangi International Airport, both by charter and scheduled flights. From Manado, the tourists toured surrounding destinations, such as Tomohon City, Lake Tondano, Bunaken Island, Lembeh, Bangka, Tahuna, Ulu and others [1].

In four years from 2015-2018, foreign tourist visits to North Sulawesi increased 6 times. Likewise, the movement of domestic tourists from around 2 million to 4 million or double, 200 percent, whereas in other regions only about 5 to 10 percent. Foreign tourists visiting North Sulawesi, especially to Manado and Bitung in 2015 reached 20 thousand people. Then in 2016 it doubled to 40 thousand. While in 2017, it increased again to 80 thousand foreign tourists and doubled again in 2018 to 120 thousand foreign tourists. Leader from tourism ministry confirm that commitment from regional leaders was one of the keys to the success of North Sulawesi in developing the tourism sector [1].
But the problem faced is there is still confusion from the behavior of businesses both micro, small, and medium related to the behavior of tourists who come to this region both domestic and foreign tourists. For this reason, it is necessary to examine the behavior of these tourists, especially in relation to buying interest in traditional MSMEs in the city of Manado, such as food and drinks, souvenirs, services, and so on. The importance of this tourism led to the need for the development of tourism in Indonesia. One of the supporters of the tourism industry is the traditional MSMEs engaged in all sectors ranging from food and beverages, crafts, culture, transportation, all of which were developed to support the tourism sector. The importance of SMEs in supporting tourism needs to implement marketing strategies in encouraging tourists to have an interest in buying products offered by this traditional MSMEs.

The purpose of this study is primarily to analyze the factors that influence the buying interest of tourists in traditional SMEs in the city of Manado.

\section{THEORETICAL FRAMEWORK}

\section{A. Small and Medium Enterprises (SMEs)}

The role of MSME cannot be doubted in support increase in community income but the understanding of MSMEs. The meaning of MSME itself is different. Definitions relating to MSMEs include [2]:

- Provisions of law No. 9 of 1995 concerning small businesses and then carried out further by government regulations number 44 of 1997 concerning partnerships, which is the meaning of MSME is as governed by Law No. 20 of 2008 MSME is a productive economic business that stands alone, which is conducted by individuals or business entities that are not constituted a subsidiary or not a branch that is owned, controlled or be a direct or indirect part of the business medium or large businesses that meet the criteria of small businesses

- According to the Central Statistics Agency in 2003 defines MSMEs according to 2 categories which are: (i) According to turnover. Small businesses are businesses that have assets still less than Rp. 200,000,000 and less 
factor productivity and low efficiency in the production process, but also low quality product made. the number of workers. A small business is a business has a workforce of 5 to 9 people. The home industry is the hiring industry of fewer than 5 people. MSMEs is a business that has capital a small beginning or small amount of assets (assets) small (limited) workers, the value of capital (assets) or amount work according to the definition given by the government or other institutions with specific objectives [2].

- According to the Ministry of Industry and Trade, UMKM is a group of modern small industries, traditional industries, and the handicraft industry which has a capital investment for machinery and equipment of Rp. 70,000,000.00 and below the business is owned by an Indonesian citizen.

The development of micro and small businesses in Indonesia is inseparable from various kinds of problems. The level of intensity and nature of the problems cannot differ not only by product type or markets served, but also differ between regions or locations, between centers, between sectors or subsectors or types of activities, and between business units in the same activity or sector [2]. However, the problems that are often faced by micro-businesses and small according to Tambunan [2]:

1) Marketing difficulties: Marketing is often considered as one of the critical obstacles for the development of micro and small businesses. One aspect of being related to marketing problems are pressures competition, both the domestic market of similar products made by businesses large and imported, as well as in the export market.

2) Financial limitations: Micro and small businesses, especially in Indonesia, face two main problems in the financial aspect: initial capital mobility (startup capital) and access to working capital, long-term financial for the investment that is needed for the growth of long-term output long.

3) Limited HR: The limitations of HR are also a serious obstacle for many micro and small businesses in Indonesia, especially in aspects of entrepreneurship, management, production engineering, product development, engineering design, quality control, business organizations, accounting, data processing, marketing techniques, and market research. This limitation impedes microenterprise and small Indonesia to be able to compete in the domestic market as well international market.

4) Raw material problems: Limitations of raw materials and other inputs are also frequent become one of the serious obstacles for output or growth continuity of production for many micro and small businesses in Indonesia. This limitation is due to overly standard prices high so it is not affordable or the amount is limited.

5) Technology limitations: Micro and small businesses in Indonesia generally still use old or traditional technology in the form of old machines or production tools that are manual. Technological backwardness this not only makes the total

\section{B. Tourism Industry}

Definition of tourism according to Law Number 10 of 2009 about tourism [3]: "Tourism is a variety of tourism activities and is supported by various facilities and services provided by the community, entrepreneurs, government, and regional governments". So tourism is a journey taken by humans to an area that is not their place of residence in at least one night with the aim of the trip not to make a living, income or livelihood at the destination.

There are five very important elements of the tourism industry, which are [4]:

1) Attractions: Attractions can be classified as site attractions and event attractions. Site attractions are a permanent physical attraction with a fixed location, namely tourist attractions in tourist destinations such as zoos, palace, and museums. Whereas event attractions are temporary attractions and their location can be changed or moved easily such as festivals, exhibitions or regional art performances.

2) Facilities (facilities required): Facilities tend to be oriented towards attractiveness in a location because facilities must be located close to the market. While staying at tourist destinations, tourists need to sleep, eat and drink, therefore lodging facilities are very much needed. In addition, there is a need for Support Industries, namely souvenir shops, laundry shops, guides, festival areas, and recreational facilities (for activities).

3) Infrastructure: Attraction and facilities cannot be achieved easily if there is no basic infrastructure. The development of infrastructure from an area is actually enjoyed by both tourists and people who also live there, so there are benefits for residents who are not tourists. Fulfilling or creating infrastructure is a way to create an atmosphere suitable for tourism development.

4) Transportations: In tourism, the progress of the world of transportation or transportation is needed because it really determines the distance and time in a tourism trip. Transportation whether land, air, or sea transportation is a major direct element that is a dynamic stage of the symptoms of tourism.

5) Hospitality: Tourists who are in an environment they do not know requires certainty of security guarantees, especially for foreign tourists who need a description of the tourist destination they will visit. Then the basic needs for security and protection must be provided and also the tenacity and hospitality of the tourist workforce need to be considered so that tourists feel safe and comfortable during the tour.

\section{Tourism Marketing}

According to Krippendorf [5] provides tourism marketing restrictions as follows, systematic and coordinated adjustments regarding policies of tourism business entities as well as policies in the tourism sector at the government, local, regional, national and international levels, in order to achieve an optimal 
in this research. After, both domestic and foreign tourists often

point of satisfaction for the needs of certain customer groups that have been applied previously, as well as to achieve an adequate level of profit .

Tourism marketing is a system and coordination implemented as a policy for companies engaged in tourism, both private and government, in the scope of local, regional, national, and international to be able to achieve tourist satisfaction by obtaining reasonable profits [6]. Basically, tourism marketing is an effort made to attract more tourists, stay longer and spend more money in a tourist destination. Such activities are formulated by economists as marketing.

Tourism marketing is very complex in nature because the product you want to market is very tied to the supplier that produces it, the agency, organization, or tourism agency that manages it. Marketing the tourism industry's products is not only limited to coordination, but it requires good cooperation between the organizations responsible for tourism development with all parties involved and related to tourism activities. The success of a marketing program in the field of marketing is largely determined by the factor of similarity in view of the role of tourism for regional development, therefore before the marketing program is implemented there must be a commitment from all relevant elements that tourism is an economic sector quick yielding and is an agent of development for the region concerned [6]. Departing in the tourism industry is an industry that is oriented to services and has properties that are very contrary to the goods industry, highly subjective, and intangible, so with its characteristics in marketing must pay attention to marketing strategies in terms of the process of segmenting, targeting, positioning, and marketing mix must be right [6].

\section{METHOD}

\section{A. Sample and Procedure}

This research is a combination research method (mix method), which is a combination of quantitative and qualitative research [7]. This research is an empirical study of the factors needed by traditional MSMEs in understanding tourist buying interest. This research starts from a survey of primary data to 100 traditional MSMEs based on food and beverages in the city of Manado, then interviews with several MSMEs which will then be examined in more depth on this research topic.

The unit of analysis in this study is the traditional MSMEs (Micro, Small and Medium Enterprises) based on food and beverages in the city of Manado. The study was conducted in several districts in the city of Manado.

\section{B. Measurement Procedures}

For survey purposes, the location taken is around traditional food and beverage-based MSMEs in Manado City. Sampling is by sampling convenience or samples based on convenience, as well as purposive sampling or samples based on certain criteria. MSMEs are taken as many as 10 MSMEs with the following criteria: MSMEs based on food and beverages, businesses carried out in Manado City, MSMEs have been running for more than a year, MSMEs have a stable consumer base and turnover, MSME owners are willing to work together visit to shop at this MSME. The number of samples taken from MSMEs is 10 respondents per MSME.

\section{RESULTS AND DISCUSSION}

TABLE I. SUMMARY OF RESEARCH RESPONDENTS DESCRIPTION

\begin{tabular}{|c|c|c|c|}
\hline Description & Info & Total & $\begin{array}{c}\text { Per cent } \\
(\%)\end{array}$ \\
\hline \multirow[t]{2}{*}{ Gender } & Men & 52 & 52 \\
\hline & Woman & 48 & 48 \\
\hline \multirow[t]{5}{*}{ Usia (years old) } & $<20$ & 5 & 5 \\
\hline & $21-30$ & 11 & 11 \\
\hline & $31-40$ & 40 & 40 \\
\hline & $41-50$ & 25 & 25 \\
\hline & $>50$ & 19 & 19 \\
\hline \multirow[t]{2}{*}{ Tourist } & National & 83 & 83 \\
\hline & Foreign & 17 & 17 \\
\hline \multirow{4}{*}{$\begin{array}{l}\text { Motivation to Buy } \\
\text { in MSMEs }\end{array}$} & Eat & 29 & 29 \\
\hline & Souvenir & 32 & 32 \\
\hline & Post in Social Media & 24 & 24 \\
\hline & Other & 15 & 15 \\
\hline \multirow{2}{*}{$\begin{array}{l}\text { Frequent visit to } \\
\text { Manado/MSMEs }\end{array}$} & Only Once & 38 & 38 \\
\hline & More Than Once & 62 & 62 \\
\hline \multirow{4}{*}{$\begin{array}{c}\text { Spending budget on } \\
\text { MSMEs }\end{array}$} & $<$ Rp. $140.000(<\$ 10)$ & 30 & 30 \\
\hline & $\begin{array}{c}\text { Rp.140.000- } \\
\text { Rp.1.400.000 (\$10-\$100) }\end{array}$ & 59 & 59 \\
\hline & $>$ Rp.1.400.000 (>\$100) & & \\
\hline & & 11 & 11 \\
\hline TOTAL & & 100 & 100 \\
\hline
\end{tabular}

Table 1 shows that out of 100 research respondents were male-dominated tourists as many as 52 respondents (52\%), aged between $31-40$ years as many as 40 respondents $(40 \%)$, domestic tourists as many as 83 respondents (83\%), the reason for buying at MSME is for souvenirs as many as 32 respondents (32\%), visiting MSMEs / to Manado more than once as many as 62 respondents $(62 \%)$, as well as the financial amount for shopping at MSMEs \$ 10- \$ 100 once shopping for 59 respondents $(59 \%)$.

Linear regression is a test to see how the independent variables influence the dependent variable [8].

TABLE II. MULTIPLE LINEAR REGRESSION ANALYSIS

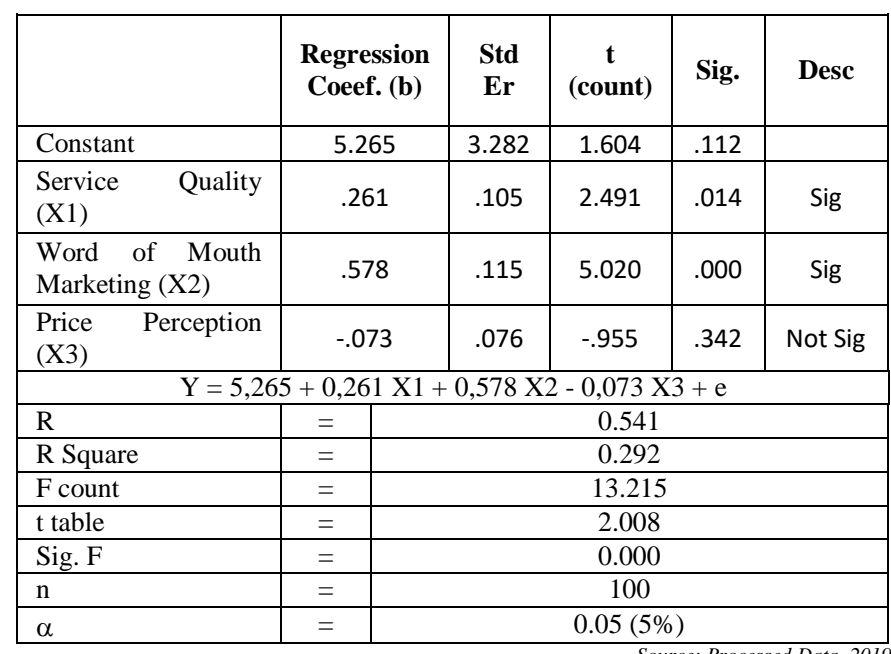


Quality on Interest in Buying tourists at traditional MSMEs in Manado City. (3) There is an influence of Word of Mouth Marketing on Interest in Buying tourists at traditional MSMEs in Manado City. (4) There is an influence of Price Perception on Interest in Buying tourists at the traditional MSMEs in Manado City.

Suggestions from this research are as follows: (1) For further researchers, it is recommended to use a larger sample so that the results further strengthen the findings of this study. (2) Further researchers are advised to conduct research on the Interest in Buying tourists at traditional SMEs in the City of Manado.

\section{ACKNOWLEDGMENT}

This research was financially supported by the author and the Faculty of Economics and Business, Sam Ratulangi University (UNSRAT) Manado, Indonesia.

\section{REFERENCES}

[1] Media KC, Look at North Sulawesi Tourism Development. Menengok Perkembangan Pariwisata Sulawesi Utara [Internet], KOMPAS.com. [24 April 2019]. Retrieved from: https://travel.kompas.com/read/2018/07/11/094457027/menengokperkembangan-pariwisata-sulawesi-utara

[2] T. Tambunan, Micro, Small and Medium Enterprises in Indonesia: important issues. Usaha Mikro Kecil dan Menengah di Indonesia : isuisu penting, Jakarta: LP3ES, 2012.

[3] The President of the RI. Tourism [Internet], Law of the Republic of Indonesia, $\quad 102009.2$ Tersedia pada: https://balitourismboard.or.id/uploads/file/reg2.pdf

[4] C. A. Tisdell, Handbook of Tourism Economics: Analysis, New Applications and Case Studies, New Jersey: World Scientific Pub Co Inc, 2013.

[5] J. Krippendorf, The Holiday Makers: Understanding the Impact of Leisure and Travel, London: Routledge, 2010.

[6] A. O. A. Yoeti, Tourism Science Introduction. Pengantar Ilmu Pariwisata, Bandung: Angkasa Offset, 2010.

[7] F. A. Hamied, Research Methods: A Guide to First-Time Researchers, Bandung: UPI Press, 2017.

[8] U. Sekaran, and R. Bougie, Research Methods. For Business: A Skill Building Approach, 5th ed. West Sussex UK: John Wiley \& Sons, 2010.
The results of research and discussion show that: (1) There is an influence of Service Quality, Word of Mouth Marketing, and Price Perception on Interest in Buying tourists at traditional MSMEs in Manado City. (2) There is an influence of Service 